\title{
Ocular tolerance and efficacy of short-term tamponade with double filling of polydimethyloxane and perfluoro-n-octane
}

This article was published in the following Dove Press journal:

Clinical Ophthalmology

5 April 20II

Number of times this article has been viewed

\author{
Stefano Zenoni ${ }^{1}$ \\ Mario R Romano \\ Sonia Palmieri' \\ Natalia Comi' \\ Edoardo Fiorentini' \\ Piero Fontana' \\ 'Ospedali Riuniti di Bergamo, \\ Bergamo, Italy; ${ }^{2}$ Istituto Clinico \\ Humanitas IRCSS, Rozzano, \\ Milan, Italy
}

Correspondence: Mario R Romano Istituto Clinico Humanitas,

Via Manzoni 56, Rozzano, Milan, Italy

Tel +390282244680

Fax +390282244660

Email romanomario@email.it
Objective: The aim of the study was to evaluate the ocular tolerance and efficacy of double filling with perfluoro-n-octane (n-C8F18) (PFO) and polydimethyloxane (PDMS) as a temporary vitreous substitute in patients with retinal detachment complicated by proliferative vitreoretinopathy (PVR).

Material and methods: Tamponade was performed in 30 eyes of 30 patients by double filling with 30\% PFO and 70\% PDMS for an average of 23 (standard deviation 2.2) days. The follow-up visits were scheduled 1 week, 1 month, and 3 months after surgery. The main outcome measures were visual acuity, intraocular pressure (IOP), PVR reproliferation, and electrophysiological parameters.

Results: The primary success rate was $80 \%$ (24/30). Fourteen patients $(46.7 \%)$ had a postoperative improvement in visual acuity, 12 patients (40.0\%) maintained their preoperative visual acuity, and four patients (13.3\%) experienced a reduction in visual acuity. The mean postoperative IOP was $19.7 \mathrm{~mm} \mathrm{Hg}(11-32 \mathrm{~mm} \mathrm{Hg})$; nine cases $(30.0 \%)$ developed an IOP increase that was treated with topical drops and/or systemic carbonic anhydrase inhibitors. The electroretinogram (ERG) and the bright flash electroretinogram (bf ERG) parameters showed a statistically significant difference of means between 4- and 8-week follow-up visits.

Conclusion: Our experience with double filling in selected cases of retinal detachment has been positive. No electroretinographic signs of retinal toxicity and a low incidence of PVR reproliferation were observed.

Keywords: double filling, proliferative vitreo-retinopathy, perfluoro-n-octane, polydimethyloxane, retinal detachment, retinal detachment electrophysiology

\section{Introduction}

Double filling endotamponade with silicone oil and perfluorocarbon liquids can be used as short-term intraocular tamponade after pars plana vitrectomy (PPV) for the treatment of complicated rhegmatogenous retinal detachment (RRD). ${ }^{1}$

The presence of perfluorocarbon liquids reduces empty space in the inferior retina, where the concentration of serum components and the migrated pigmented retinal epithelium (RPE) cells are localized in the presence of "light tamponades" (gas or oil), thereby minimizing the risk of developing proliferative vitreoretinopathy (PVR) in the lower retina. ${ }^{1,2}$

The retinal tolerance of perfluorocarbon liquids is still controversial because their highly specific gravity or excitotoxicity due to aqueous exclusion can potentially cause mechanical damage to the retina when used as a short-term vitreous substitute. ${ }^{3}$ We evaluated double filling with perfluoro-n-octane (PFO) 70\% (n-C8F18, Fluoron GmbH, 
Ulm, Germany) and polydimethyloxane (PDMS) 30\% (RS OIL 1000 centistokes, AL.CHI.MI.A. srl) as a short-term intraocular tamponade after PPV for the treatment of complicated RRD. PFO was chosen due to its purity, its chemical and physical inertness, and its lack of toxicity. ${ }^{4}$ Safe ocular use of PFO has already been described. ${ }^{5}$ Only $30 \%$ ocular volume was filled in order to avoid the formation of meniscus in the macular area and to minimize the weight of the PFO bubble on the retina.

The aim of the present study was to evaluate the ocular tolerance and efficacy of this double filling on human eyes. The main outcome measures were electrophysiological parameters, visual acuity, intraocular pressure (IOP), and PVR incidence after removal of tamponade.

\section{Material and methods}

Approval for this study was obtained from the central office of the Research and Ethics Committee of the hospital according to the tenets of the Declaration of Helsinki. Fully informed consent was obtained before surgery in all cases.

This study was a prospective, interventional case series of 30 eyes of 30 patients ( 15 males and 15 females) affected by complicated retinal detachment with PVR (D1-D2) ${ }^{6}$ who underwent PPV with an endotamponade of $30 \%$ PFO and $70 \%$ PDMS.

In all patients, a best-corrected Snellen visual acuity (BCVA) converted into logarithm of the minimum angle of resolution (logMAR), IOP, anterior segment evaluation with slit lamp, and fundus oculi examination were performed. The same surgeon operated on all the patients.

The follow-up visits were scheduled 1 week, 1 month, and 3 months after surgery. We also performed electroretinographic evaluations (electroretinogram [ERG] and bright flash electroretinogram [bfERG]) in 20 of the 30 eyes 2 weeks and 8 weeks after removal of the double fill tamponade.

\section{Surgical technique}

After conjunctival peritomy, a standard three-port PPV with a 20-gauge system was performed. Posterior vitreous detachment was induced when not already present, using aspiration with the vitrectomy handpiece, and the posterior hyaloid was removed. The vitreous cavity was expanded with injection of the perfluorocarbon liquid (PFCL) perfluorodecalin (HPF10, AL.CHI.MI.A. srl, Ponte S.Nicolò, Italy) over the posterior pole to obtain retinal flattening. The vitreous base was carefully shaved over $360^{\circ}$ and all the membranes were dissected. Epiretinal membrane peeling was performed in all cases, whereas peripheral retinectomies were performed in 21 out of 30 cases in order to mobilize the retina and relieve the traction. Argon laser endophotocoagulation was performed with a 20-gauge illuminated probe in order to obtain a barrage around the retinal breaks and rhegmatogenous retinal degenerations. PFCL was then removed and the vitreous cavity was expanded with air. At this time, PFO 30\% and PDMS 70\% were injected one after the other under air infusion. The 30\%-70\% filling was estimated intraoperatively and was not preoperatively calculated. No scleral buckle was used in those cases.

After an average of 23.4 (standard deviation [SD] 2.2) days (range 19-27 days), the double fill tamponade was removed and the cataract surgery was performed at the same time in $17 / 22$ phakic patients.

\section{Electroretinographic examination}

ERGs were recorded using standard electrophysiological methods. Pupils were dilated with tropicamide 1\% drops 30 minutes before recording. The electrical activity of the retina was evoked with a stroboscopic full-field illumination.

Electrofunctional evaluations were carried out with the following technique. After corneal anesthesia with benoxinate drops, the ERG-Jet contact electrode was positioned in the eye that previously underwent vitreoretinal surgery. The ground electrode was a skin silver chloride fixed at the front. The ERG was recorded using International Society for Clinical Electrophysiology of Vision methodology with white flashes at a frequency of 0.5 Hertz. ${ }^{7}$ White flashes of $1.7 \mathrm{Cd} / \mathrm{sm} / \mathrm{sec}$ were applied every 5 seconds in the Gauzfeld dome after photopic adaptation. Five readings amplified 2000 times and with a $0.1-500 \mathrm{~Hz}$ frequency band were averaged with a signal analyzer.

The bf ERG evaluation was carried out using the above methodology at $53.8 \mathrm{~cd} / \mathrm{sm} / \mathrm{sec}$ after 20 minutes of dark adaptation (ie, scotopic adaptation).

Statistical comparisons (Systat statistical packages, Evanston, IL, USA) were made using Spearman's rank correlation (iris fluorescein angiography stage) and paired $t$-test. A random probability of $<0.05$ was considered statistically significant.

\section{Results}

\section{Preoperative data}

A total of 30 eyes in 30 patients (15/15 male/female) underwent vitrectomy with double filling (with 70\% PDMS and 30\% PFO) over a 12-month period in a single institution. The descriptive statistics for the patients' preoperative status are summarized in Table 1 . The mean age was 54.79 years (range $24-83$ years). 
Table I Demographics data of patients

\begin{tabular}{|c|c|c|c|c|c|c|c|}
\hline Patient & Age & Gender & $\begin{array}{l}\text { Preoperative visual } \\
\text { acuity (LogMAR) }\end{array}$ & $\begin{array}{l}\text { Preoperative } \\
\text { IOP }\end{array}$ & Lens & Other & High myopia \\
\hline $\mathrm{G} / \mathrm{A}$ & 24 & $M$ & 3,0 & 16 & Clear & Posterior break & $x$ \\
\hline$S / M$ & 83 & M & 3,0 & 14 & Cortical opacities & Post-traumatic RD & \\
\hline $\mathrm{T} / \mathrm{T}$ & 30 & M & 2,0 & 4 & Pseudophakia & Posterior break & $x$ \\
\hline CM/D & 77 & $\mathrm{~F}$ & 2,0 & 13 & Initial nuclear sclerosis & Post-traumatic RD & \\
\hline $\mathrm{G} / \mathrm{B}$ & 67 & $\mathrm{~F}$ & 3,0 & 16 & Pseudophakia & Posterior break & \\
\hline$A / P$ & 50 & $\mathrm{~F}$ & $\mathrm{I}, 0$ & 17 & Nuclear sclerosis & Post-traumatic RD & \\
\hline $\mathrm{V} / \mathrm{V}$ & 57 & $\mathrm{~F}$ & 2,0 & 14 & Nuclear sclerosis & Posterior break & $x$ \\
\hline $\mathrm{F} / \mathrm{T}$ & 59 & M & 3,0 & 12 & Pseudophakia & & \\
\hline $\mathrm{T} / \mathrm{F}$ & 25 & $\mathrm{~F}$ & 3,0 & 18 & Clear & Posterior break & $x$ \\
\hline$E / G$ & 82 & M & 2,0 & 15 & $\begin{array}{l}\text { Post-traumatic lens } \\
\text { dislocation }\end{array}$ & Post-traumatic RD & \\
\hline L/L & 72 & M & 3,0 & 14 & Clear & Post-traumatic RD & \\
\hline $\mathrm{G} / \mathrm{M}$ & 65 & M & 3,0 & 4 & Cortical opacities & & \\
\hline$A / B$ & 42 & $M$ & 2,0 & 13 & Pseudophakia & Posterior break & $x$ \\
\hline $\mathrm{G} / \mathrm{C}$ & 60 & M & 2,0 & 16 & Clear & & \\
\hline $\mathrm{G} / \mathrm{P}$ & 47 & M & 3,0 & 17 & Pseudophakia & Post-traumatic RD & \\
\hline $\mathrm{G} / \mathrm{V}$ & 43 & $M$ & 3,0 & 18 & Nuclear sclerosis & Posterior break & $x$ \\
\hline$S / P$ & 64 & M & $\mathrm{I}, 0$ & 18 & Nuclear sclerosis & Post-traumatic RD & \\
\hline $\mathrm{D} / \mathrm{B}$ & 70 & $M$ & 3,0 & 14 & Pseudophakia & Post-traumatic RD & \\
\hline$C / A$ & 41 & $M$ & 3,0 & 12 & Clear & Posterior break & $x$ \\
\hline $\mathrm{N} / \mathrm{C}$ & 37 & M & 3,0 & 10 & Initial nuclear sclerosis & Posterior break & $x$ \\
\hline$B / T$ & 67 & $\mathrm{~F}$ & 3,0 & 18 & Clear & Posterior break & \\
\hline$S / E$ & 49 & $\mathrm{~F}$ & 2,0 & 10 & Clear & Post-traumatic RD & \\
\hline $\mathrm{G} / \mathrm{P}$ & 57 & $\mathrm{~F}$ & 3,0 & 23 & Pseudophakia & Post-traumatic RD & \\
\hline $\mathrm{A} / \mathrm{A}$ & 50 & $\mathrm{~F}$ & 3,0 & 17 & Clear & & \\
\hline L/M & 70 & $\mathrm{~F}$ & 1,0 & 17 & Nuclear sclerosis & Post-traumatic RD & \\
\hline $\mathrm{G} / \mathrm{V}$ & 37 & $\mathrm{~F}$ & 2,0 & 16 & Nuclear sclerosis & Posterior break & $x$ \\
\hline$N / S$ & 24 & $\mathrm{~F}$ & 3,0 & 15 & Clear & & $x$ \\
\hline $\mathrm{G} / \mathrm{S}$ & 83 & $\mathrm{~F}$ & 3,0 & 16 & Pseudophakia & & \\
\hline$M / D$ & 55 & $\mathrm{~F}$ & 3,0 & 18 & Clear & Post-traumatic RD & \\
\hline $\mathrm{F} / \mathrm{F}$ & 52 & $\mathrm{~F}$ & 2,0 & 15 & Nuclear sclerosis & Posterior break & \\
\hline
\end{tabular}

Abbreviations: IOP, intraocular pressure; RD, retinal detachment.

The median visual acuity was $2.50 \log$ Mar and the median preoperative IOP was $14.7 \mathrm{~mm} \mathrm{Hg}$ (range 4-23 mm Hg). Eight patients were pseudophakic $(26.7 \%)$ and 11 patients had mild lens opacity $(36.7 \%)$. One patient had a post-traumatic dislocation of the lens $(3.3 \%)$ and therefore underwent phacoemulsification with intraocular lens implantation at the time of vitrectomy. A total of 12 patients had a posterior break (40.0\%) and 10 subjects had high myopia (33.3\%). Twelve patients had post-traumatic retinal detachment $(40.0 \%)$.

\section{Before removal of double fill tamponade}

The mean IOP was $21.7 \mathrm{~mm} \mathrm{Hg}$ (range 10-40 mm Hg). In 16 cases, IOP increased and was treated with topical or systemic therapy (53.3\%). In two patients, we observed small droplet emulsification in the inferior chamber or on the surface of the double filling bubble in the vitreous chamber (6.7\%). Eleven patients (36.7\%) developed cataract. These complications are reported in Table 2.

\section{After removal of double fill tamponade}

Double filling was exchanged with balanced salt solution (BSS) in 20 eyes (67\%), with PDMS in six eyes (20\%), and with air in four eyes (13\%). The primary success rate, without further procedures, was $80 \%$ (24 out of 30 ). Six cases developed epiretinal membrane (20.0\%) in the superior retinal quadrants. These eyes underwent peeling of epiretinal membranes at the time of double filling removal, after which time a tamponade of $1000 \mathrm{cSt}$ silicon oil was added.

\section{Functional outcome}

Two months after removal of the tamponade double filling (Table 3$)$, the mean visual acuity was $1.94 \operatorname{LogMar}(P=0.41$ $t$-test). Fourteen of 30 patients had an improvement in visual acuity postoperatively (46.7\%), 12/30 patients maintained their preoperative visual acuity $(40.0 \%)$, and $4 / 30$ patients experienced a reduction in visual acuity (13.3\%). The mean postoperative IOP was $19.7 \mathrm{~mm} \mathrm{Hg}$ (SD $5.5 \mathrm{~mm}$ 
Table 2 Pre-double filling removal data

\begin{tabular}{|c|c|c|c|c|c|c|c|c|c|}
\hline \multirow[t]{2}{*}{ Patient } & \multirow[t]{2}{*}{ Age } & \multirow[t]{2}{*}{ Gender } & \multirow{2}{*}{$\begin{array}{l}\text { Preoperative } \\
\text { IOP }\end{array}$} & \multirow[t]{2}{*}{ Lens } & \multirow{2}{*}{$\begin{array}{l}\text { Double filling } \\
\text { removal (days) }\end{array}$} & \multicolumn{4}{|c|}{ Complications (Pre-double filling removal) } \\
\hline & & & & & & PVR & $\begin{array}{l}\text { IOP } \\
\text { increase }\end{array}$ & Emulsion & Cataract \\
\hline $\mathrm{G} / \mathrm{A}$ & 24 & M & 18 & Clear & 19 & $x$ & $x$ & & \\
\hline S/M & 83 & M & 19 & Cortical opacities & 27 & & $x$ & & $x$ \\
\hline $\mathrm{T} / \mathrm{T}$ & 30 & $M$ & 10 & Pseudophakia & 23 & & & & \\
\hline CM/D & 77 & $\mathrm{~F}$ & 15 & $\begin{array}{l}\text { Initial nuclear } \\
\text { sclerosis }\end{array}$ & 24 & $x$ & $x$ & & $x$ \\
\hline G/B & 67 & $\mathrm{~F}$ & 18 & Pseudophakia & 20 & & & & \\
\hline $\mathrm{A} / \mathrm{P}$ & 50 & $\mathrm{~F}$ & 27 & Nuclear sclerosis & 26 & & $x$ & $x$ & $x$ \\
\hline $\mathrm{V} / \mathrm{V}$ & 57 & $\mathrm{~F}$ & 20 & Nuclear sclerosis & 23 & & $x$ & & $x$ \\
\hline $\mathrm{F} / \mathrm{T}$ & 59 & $M$ & 32 & Pseudophakia & 21 & & & & \\
\hline $\mathrm{T} / \mathrm{F}$ & 25 & $\mathrm{~F}$ & 40 & Clear & 25 & & $x$ & & \\
\hline E/G & 82 & $M$ & 17 & $\begin{array}{l}\text { Post-traumatic lens } \\
\text { dislocation }\end{array}$ & 26 & & $x$ & & \\
\hline L/L & 72 & $M$ & 29 & Clear & 23 & $x$ & $x$ & & \\
\hline $\mathrm{G} / \mathrm{M}$ & 65 & $M$ & 11 & Cortical opacities & 23 & & & & $x$ \\
\hline$A / B$ & 42 & $M$ & 25 & Pseudophakia & 21 & & & $x$ & \\
\hline $\mathrm{G} / \mathrm{C}$ & 60 & $M$ & 25 & Clear & 26 & & & & \\
\hline $\mathrm{G} / \mathrm{P}$ & 47 & M & 24 & Pseudophakia & 27 & $x$ & $x$ & & \\
\hline $\mathrm{G} / \mathrm{V}$ & 43 & $M$ & 28 & Nuclear sclerosis & 23 & & & & $x$ \\
\hline$S / P$ & 64 & $M$ & 24 & Nuclear sclerosis & 22 & $x$ & $x$ & & $x$ \\
\hline$D / B$ & 70 & $M$ & 14 & Pseudophakia & 25 & & & & \\
\hline $\mathrm{C} / \mathrm{A}$ & 41 & $M$ & 30 & Clear & 21 & $x$ & $x$ & & \\
\hline $\mathrm{N} / \mathrm{C}$ & 37 & M & 27 & $\begin{array}{l}\text { Initial nuclear } \\
\text { sclerosis }\end{array}$ & 23 & & $x$ & & $x$ \\
\hline $\mathrm{B} / \mathrm{T}$ & 67 & $\mathrm{~F}$ & 18 & Clear & 27 & & & & \\
\hline$S / E$ & 49 & $\mathrm{~F}$ & 10 & Clear & 23 & & & & \\
\hline $\mathrm{G} / \mathrm{P}$ & 57 & $\mathrm{~F}$ & 32 & Pseudophakia & 24 & & $x$ & & \\
\hline $\mathrm{A} / \mathrm{A}$ & 50 & $\mathrm{~F}$ & 17 & Clear & 22 & & & & \\
\hline$L / M$ & 70 & $\mathrm{~F}$ & 17 & Nuclear sclerosis & 23 & & & & $x$ \\
\hline $\mathrm{G} / \mathrm{V}$ & 37 & $\mathrm{~F}$ & 16 & Nuclear sclerosis & 23 & & & & $x$ \\
\hline$N / S$ & 24 & $\mathrm{~F}$ & 25 & Clear & 25 & & $x$ & & \\
\hline $\mathrm{G} / \mathrm{S}$ & 83 & $\mathrm{~F}$ & 18 & Pseudophakia & 21 & & & & \\
\hline$M / D$ & 55 & $\mathrm{~F}$ & 15 & Clear & 20 & & $x$ & & \\
\hline$F / F$ & 52 & $\mathrm{~F}$ & 30 & Nuclear sclerosis & 26 & & $x$ & & $x$ \\
\hline
\end{tabular}

Abbreviations: IOP, intraocular pressure; PVR, proliferative vitreoretinopathy.

$\mathrm{Hg}$ ) (range 11-32 $\mathrm{mm} \mathrm{Hg}$ ); nine cases developed an increase in IOP that was treated with topical drops and/or systemic carbonic anhydrase inhibitors (30.0\%). In three cases $(10.0 \%)$, cystoid macular edema confirmed by ocular coherence tomography was observed.

\section{Electrophysiological outcome}

Electrofunctional evaluations (ERG and bf ERG) were carried out in the 20/30 eyes (67\%) in which the double tamponade was substituted for BSS (Tables 4, 5 and 6).

Mean ERG amplitudes 2 and 8 weeks after removal of the tamponade were 55.6 (SD 24.7) and 61.6 (SD 26.0), respectively. Mean amplitudes of bf ERG 2 and 8 weeks after removal of double filling were 107.2 (SD 49.7) and 128.9 (SD 65.8), respectively. With both techniques, the difference of means was statistically significant (Tables 4,5 and 6).

\section{Discussion}

PVR can be defined as the growth and contraction of cellular membranes within the vitreous cavity and both retinal surfaces after RRD. This process, a frequent cause of failure after surgical therapy for RRD, may result in recurrent detachment by reopening otherwise successfully treated retinal breaks or creating new retinal breaks. ${ }^{8}$ PVR is a dynamic biologic phenomenon with no currently available effective pharmacologic therapy. ${ }^{9}$ Vitreal substitutes used as stabilizing substances that close the communication between the pre- and subretinal space minimize this proliferative phenomenon. PDMS is the first-choice vitreous substitute currently used for the treatment of retinal detachment complicated by PVR, multiple retinal tears, or giant retinal tears.

Chemically, silicone oil is generated by polymerization of dimethylsiloxane units or a low-molecular-weight cyclic 
Table 3 Postoperative data (3 months)

\begin{tabular}{|c|c|c|c|c|c|c|c|}
\hline \multirow[t]{2}{*}{ Patient } & \multirow[t]{2}{*}{ Age } & \multirow[t]{2}{*}{ Gender } & \multirow{2}{*}{$\begin{array}{l}\text { Post-operative visual } \\
\text { acuity (LogMAR) }\end{array}$} & \multirow{2}{*}{$\begin{array}{l}\text { Post-operative } \\
\text { IOP }\end{array}$} & \multicolumn{3}{|c|}{ Complications } \\
\hline & & & & & CME & $\begin{array}{l}\text { IOP increase } \\
\text { (medical therapy) }\end{array}$ & PVR \\
\hline $\mathrm{G} / \mathrm{A}$ & 24 & $M$ & 1,3 & 18 & & & \\
\hline$S / M$ & 83 & $M$ & 3,0 & 16 & & & \\
\hline $\mathrm{T} / \mathrm{T}$ & 30 & $M$ & 3,0 & 11 & & & $x$ \\
\hline$C M / D$ & 77 & $\mathrm{~F}$ & 3,0 & 27 & & $x$ & \\
\hline $\mathrm{G} / \mathrm{B}$ & 67 & $\mathrm{~F}$ & 2,0 & 19 & & & \\
\hline $\mathrm{A} / \mathrm{P}$ & 50 & $\mathrm{~F}$ & $\mathrm{I}, 0$ & 18 & & & \\
\hline $\mathrm{V} / \mathrm{V}$ & 57 & $\mathrm{~F}$ & $\mathrm{I}, 3$ & 20 & & $x$ & \\
\hline$F / T$ & 59 & $M$ & 3,0 & 16 & & & \\
\hline$T / F$ & 25 & $\mathrm{~F}$ & 1,0 & 32 & & $x$ & \\
\hline$E / G$ & 82 & M & 2,0 & 18 & & & \\
\hline $\mathrm{L} / \mathrm{L}$ & 72 & $M$ & 3,0 & 16 & & & $x$ \\
\hline $\mathrm{G} / \mathrm{M}$ & 65 & $M$ & 3,0 & 11 & $x$ & & \\
\hline $\mathrm{A} / \mathrm{B}$ & 42 & $M$ & 3,0 & 27 & & $x$ & \\
\hline $\mathrm{G} / \mathrm{C}$ & 60 & $M$ & 0,7 & 18 & & & \\
\hline $\mathrm{G} / \mathrm{P}$ & 47 & $M$ & 2,0 & 19 & & & $x$ \\
\hline $\mathrm{G} / \mathrm{V}$ & 43 & $M$ & 1,0 & 18 & & & \\
\hline$S / P$ & 64 & $M$ & 1,0 & 20 & & $x$ & \\
\hline $\mathrm{D} / \mathrm{B}$ & 70 & $M$ & 3,0 & 16 & & & \\
\hline C/A & 41 & $M$ & 1,0 & 32 & & $x$ & \\
\hline $\mathrm{N} / \mathrm{C}$ & 37 & $M$ & 2,0 & 18 & & & \\
\hline $\mathrm{B} / \mathrm{T}$ & 67 & $\mathrm{~F}$ & 3,0 & 16 & $x$ & & \\
\hline$S / E$ & 49 & $\mathrm{~F}$ & 3,0 & 27 & & $x$ & \\
\hline $\mathrm{G} / \mathrm{P}$ & 57 & $\mathrm{~F}$ & 0,7 & 18 & & & \\
\hline $\mathrm{A} / \mathrm{A}$ & 50 & $\mathrm{~F}$ & 2,0 & 19 & & & \\
\hline L/M & 70 & $\mathrm{~F}$ & 1,0 & 18 & & & \\
\hline $\mathrm{G} / \mathrm{V}$ & 37 & $\mathrm{~F}$ & 1,0 & 20 & & $x$ & \\
\hline $\mathrm{N} / \mathrm{S}$ & 24 & $\mathrm{~F}$ & 1,3 & 16 & & & \\
\hline $\mathrm{G} / \mathrm{S}$ & 83 & $\mathrm{~F}$ & 3,0 & 16 & $x$ & & \\
\hline$M / D$ & 55 & $\mathrm{~F}$ & 1,0 & 32 & & $x$ & \\
\hline $\mathrm{F} / \mathrm{F}$ & 52 & $\mathrm{~F}$ & 2,0 & 18 & & & \\
\hline
\end{tabular}

Abbreviations: CME, cystoid macular edema; IOP, intraocular pressure; PVR, proliferative vitreoretinopathy.

Table 4 Electroretinogram evaluation data at 2 weeks and 8 weeks after surgery

\begin{tabular}{|c|c|c|c|c|c|c|c|}
\hline \multicolumn{4}{|l|}{ ERG B } & \multicolumn{4}{|c|}{ bfERG B } \\
\hline Patient & Ist exam & 2nd exam & Absolute delta & Patient & Ist exam & 2nd exam & Absolute delta \\
\hline $\mathrm{G} / \mathrm{A}$ & 65,8 & 62,9 & $-2,9$ & $\mathrm{G} / \mathrm{A}$ & 142,9 & 115,4 & $-27,5$ \\
\hline$S / M$ & 76,9 & 59,8 & $-17, \mid$ & $S / M$ & 160,5 & 200,5 & 40 \\
\hline$L / M$ & 90,9 & 88,7 & $-2,2$ & $\mathrm{~L} / \mathrm{M}$ & $|57|$, & 138,2 & $-18,9$ \\
\hline$C M / D$ & 10,4 & 17,3 & 6,9 & $C M / D$ & 36,2 & 46,1 & 9,9 \\
\hline $\mathrm{G} / \mathrm{B}$ & 53,9 & 80,2 & 26,3 & $\mathrm{G} / \mathrm{B}$ & 156,2 & 162,7 & 6,5 \\
\hline$A / P$ & 83,1 & 96,1 & 13 & $\mathrm{~A} / \mathrm{P}$ & 135,4 & 191,9 & 56,5 \\
\hline $\mathrm{V} / \mathrm{V}$ & 57 & 55,4 & $-1,6$ & $\mathrm{~V} / \mathrm{V}$ & 98,6 & 127,8 & 29,2 \\
\hline$T / F$ & 56,4 & 73,1 & 16,7 & $T / F$ & 109,6 & 213,9 & 104,3 \\
\hline $\mathrm{L} / \mathrm{L}$ & 43,8 & 53,7 & 9,9 & $\mathrm{~L} / \mathrm{L}$ & 76,9 & 107,2 & 30,3 \\
\hline $\mathrm{G} / \mathrm{M}$ & 19,8 & 13,9 & $-5,9$ & $\mathrm{G} / \mathrm{M}$ & 14,2 & 8,3 & $-5,9$ \\
\hline $\mathrm{G} / \mathrm{C}$ & 64,2 & 77,9 & 13,7 & $\mathrm{G} / \mathrm{C}$ & 43,1 & 18,8 & $-24,3$ \\
\hline $\mathrm{G} / \mathrm{V}$ & 75,1 & 71,8 & $-3,3$ & $\mathrm{G} / \mathrm{V}$ & 120,9 & 161,1 & 40,2 \\
\hline $\mathrm{N} / \mathrm{C}$ & 88,5 & 90 & 1,5 & $\mathrm{~N} / \mathrm{C}$ & 147,9 & 119,2 & $-28,7$ \\
\hline $\mathrm{C} / \mathrm{A}$ & 12,2 & 24,6 & 12,4 & $\mathrm{C} / \mathrm{A}$ & 57,8 & 77,9 & 20,1 \\
\hline $\mathrm{A} / \mathrm{A}$ & 52,4 & 68,9 & 16,5 & $\mathrm{~A} / \mathrm{A}$ & 179,4 & $186, \mid$ & 6,7 \\
\hline $\mathrm{N} / \mathrm{S}$ & 82,8 & 95,7 & 12,9 & $\mathrm{~N} / \mathrm{S}$ & $|5|, 8$ & 188,5 & 36,7 \\
\hline$M / D$ & 56 & 55,2 & $-0,8$ & $M / D$ & 114,6 & 142,5 & 27,9 \\
\hline $\mathrm{F} / \mathrm{F}$ & 58,6 & 75,2 & 16,6 & $\mathrm{~F} / \mathrm{F}$ & 125,2 & 219,7 & 94,5 \\
\hline$S / E$ & 44,4 & 54,3 & 9,9 & $S / E$ & 87,1 & 131,6 & 44,5 \\
\hline $\mathrm{D} / \mathrm{B}$ & 20,4 & 16,7 & $-3,7$ & $D / B$ & 29 & 21,1 & $-7,9$ \\
\hline
\end{tabular}


Table 5 Electroretinogram (full-field) results ${ }^{\mathrm{a}}$

Mean at 2 weeks after double filling removal (standard deviation)

Mean at 8 weeks after double filling removal

(standard deviation)

$95 \%$ confidence interval for means difference

of a correlated sample with paired data

(t $\alpha / 2$ at 19 degrees of freedom is equal to 2.093)

Note: ${ }^{\text {a }}$ The interval excludes the 0 so that the difference of means is statistically significant.

siloxane and constituted of polymer chains of different length. It is an optically clear hydrophobic and lipophilic fluid with different viscosity $(1000-5700 \mathrm{cSt})$ and is slightly lighter than water (specific gravity $0.97 \mathrm{~g} / \mathrm{cm}^{3}$ ). It is permeable to oxygen, does not mix with water, and has a high surface tension toward water $(35 \mathrm{mN} / \mathrm{m}) .{ }^{10}$

PFCLs consist of a hydrocarbon molecule in which hydrogen atoms are replaced by fluorine atoms. PFO is a saturated PFCL with highly stable carbon-fluorine bonds that make it virtually inert. It has a highly specific gravity $\left(1.70 \mathrm{~g} / \mathrm{cm}^{3}\right)$, low viscosity $(0.8 \mathrm{cSt})$, and an interface tension toward water $55 \mathrm{mNm} .{ }^{11}$

Both silicon oil and PFCL are hydrophobic, and surface energy is lowest when the two liquids are in contact. The two liquids prefer to be in contact and exclude aqueous from the interface that is displaced laterally. The double bubble effectively gives good contact only to the inferior retina, whereas the tamponade effect in the superior retina is less effective.

Inferior compartmentalization is an important cause of PVR development. In order to reduce this phenomenon and fill the inferior part of the retina at the same time, other kinds of tamponades have been tested, such as heavy silicone oils, double filling with PDMS, fluorosilicone, semifluorinated alkanes, heavy silicone oils, and perfluorocarbon liquids. ${ }^{1,12,13}$

Perfluorocarbon liquids are currently used as intraoperative tools in the management of retinal detachment due to their ability to displace subretinal fluid and to stabilize the retina during surgical procedures.

Table 6 Bright flash electroretinogram results ${ }^{\mathrm{a}}$

\begin{tabular}{ll}
\hline $\begin{array}{l}\text { Mean at } 2 \text { weeks after double filling removal } \\
\text { (standard deviation) }\end{array}$ & $107.2 \mathrm{mV}(49.7)$ \\
$\begin{array}{l}\text { Mean at } 8 \text { weeks after double filling removal } \\
\text { (standard deviation) }\end{array}$ & $128.9 \mathrm{mV}(65.8)$ \\
$95 \%$ confidence interval for means difference & $4.43 ; 38.98$ \\
of a correlated sample with paired data & \\
(t $\alpha / 2$ at 19 degrees of freedom is equal to 2.093) & \\
\hline
\end{tabular}

Note: ${ }^{\text {a }}$ The interval excludes the 0 so that the difference of means is statistically significant.
In order to avoid potential retinal damage caused by their highly specific gravity $\left(1.94-1.76 \mathrm{~g} / \mathrm{cm}^{3}\right)$ and low viscosity $(2.7-0.8 \mathrm{cSt}),{ }^{14}$ the perfluorocarbon liquids are usually exchanged with silicone oil before the end of the procedure. Their retinal tolerance is still controversial, and studies evaluating prolonged tamponade with these liquids are discordant. Some studies in rabbit eyes demonstrated retinal damage to photoreceptors and retinal pigment epithelium with areas of atrophy and necrosis, mainly of mechanical origin. ${ }^{15-18}$ Other histologic and electroretinographic studies performed on rabbit and pig eyes demonstrated their tolerance and safety profile. ${ }^{19-21}$

We investigated the ocular tolerance and efficacy of a double filling left in place in the vitreous chamber for an average of 3 weeks in order to allow the formation of a chorioretinal scar. When proliferation of immature membranes occurred, they were peeled at the same time as the double filling exchange. The choice of $30 \%$ PFO was made to avoid the formation of meniscus in the macular area and to minimize the weight of the PFO bubble on the retina.

Improvements of ERG and bf ERG after removal of the double fill tamponade supported its retinal tolerability and demonstrated recovery of the retinal tissues from the surgical procedure. Because ERG is an expression of electrical function of the entire retinal tissue and not only of the macula, it is not possible to statistically correlate visual acuity and ERG parameters.

Even if double filling is potentially toxic, when removed within 3 weeks, any retinal surface toxicity is temporary, as indicated by the improvement of electrophysiological parameters after its removal. Postoperative IOP increased in $30 \%$ of our patients and in every case was successfully treated with topical therapy. Further proliferation had a low incidence $(10 \%)$ and electroretinography did not demonstrate retinal damage.

Regarding the anatomic results, the Silicon Study Report $11^{22}$ showed at 36 months an anatomic success in $86 \%$ of cases treated with silicon oil for retina detachment complicated by severe PVR with BCVA $\geq 10 / 50$ in $24 \%$ of cases.

A recent retrospective study on 33 eyes treated with heavy silicon oil for complicated retinal detachment reported an anatomic success rate of $87.9 \%$ with first surgery with BCVA. ${ }^{23}$ In our series, the primary success rate, without further procedures, was $80 \%$ with an improvement of BCVA in $46.7 \%$ of the cases.

This study indicates that short-term double filling with $30 \%$ PFO and $70 \%$ PDMS can be considered effective 
with no permanent functional retinal toxicity. The main limitations of our study were the low number of patients and the inherent limitations of ERG in detecting other types of retinal damages. Further studies are necessary to compare the ocular tolerance and advantages of temporary endotamponade double filling with other tamponades in the treatment of complicated RRD.

\section{Disclosure}

The authors report no conflicts of interest in this work.

\section{References}

1. Bottoni F, Arpa P, Vinciguerra P, et al. Combined silicone and fluorosilicone oil tamponade (double filling) in the management of complicated retinal detachment. Ophthalmologica. 1992;204:77-81.

2. De Molfetta V, Bottoni F, Arpa P, et al. The effect of simultaneous internal tamponade on fluid compartmentalization and its relationship to cell proliferation. Retina. 1992;12:S40-S45.

3. Osterholz J, Winter M, Winkler J, et al. Retinal damage by perfluorocarbon liquids - a question of specific gravity? Intraocular pressure peaks and shearing forces. Klin Monbl Augenheilkd. 2009;226:38-47.

4. Bourke RD, Simpson RN, Cooling RJ, Sparrow JR. The stability of perfluoro-N-octane during vitreoretinal procedures. Arch Ophthalmol. 1996;114:537-544.

5. Rofail M, Lee LR. Perfluoro-n-octane as a postoperative vitreoretinal tamponade in the management of giant retinal tears. Retina. 2005;25: 897-901.

6. Machemer R, Aaberg TM, Freeman HM, et al. An updated classification of retinal detachment with proliferative vitreoretinopathy. $\mathrm{Am} \mathrm{J}$ Ophthalmol. 1991;112:159-165.

7. Marmor MF, Fulton AB, Holder GE, et al. ISCEV standard for fullfield clinical electroretinography (2008 update). Doc Ophthalmol. 2009;118:69-77.

8. Glaser BM, Cardin A, Biscoe B. Proliferative vitreoretinopathy. The mechanism of development of vitreoretinal traction. Ophthalmology. 1987;94:327-332.

9. Wickham L, Bunce C, Wong D, et al. Randomized controlled trial of combined 5-fluorouracil and low-molecular-weight heparin in the management of unselected rhegmatogenous retinal detachments undergoing primary vitrectomy. Ophthalmology. 2007;114:698-704.
10. Kreiner CF. Chemical and physical aspects of clinically applied silicones. Dev Ophthalmol. 1987;14:11-19.

11. Loewenstein A, Humayun MS, de Juan E Jr, et al. Perfluoroperhydrophenanthrene versus perfluoro-n-octane in vitreoretinal surgery. Ophthalmology. 2000;107:1078-1082.

12. Herbrig E, Sandner D, Engelmann K. Anatomical and functional results of endotamponade with heavy silicone oil - Densiron 68 - in complicated retinal detachment. Ophthalmic Res. 2007;39:198-206.

13. Herbert E, Stappler T, Wetterqvist C, et al. Tamponade properties of double-filling with perfluorohexyloctane and silicone oil in a model eye chamber. Graefes Arch Clin Exp Ophthalmol. 2004;242:250-254.

14. Velikay M, Stolba U, Wedrich A, et al. The effect of chemical stability and purification of perfluorocarbon liquids in experimental extended-term vitreous substitution. Graefes Arch Clin Exp Ophthalmol. 1995;233:26-30.

15. Devin F, Jourdan T, Saracco JB, Lucciani A. Experimental tolerability of perfluorodecalin in prolonged intraocular tamponade. $\mathrm{JFr}$ Ophtalmol. 1995; 18:268-274.

16. Orzalesi N, Migliavacca L, Bottoni F, Miglior S. Experimental shortterm tolerance to perfluorodecalin in the rabbit eye: a histopathological study. Curr Eye Res. 1998;17:828-835.

17. Eckardt C, Nicolai U, Winter M, Knop E. Experimental intraocular tolerance to liquid perfluorooctane and perfluoropolyether. Retina. 1991;11:375-384.

18. Chang S, Sparrow JR, Iwamoto T, et al. Experimental studies of tolerance to intravitreal perfluoro-n-octane liquid. Retina. 1991;11:367-374.

19. Mackiewicz J, Maaijwee K, Luke C, et al. Effect of gravity in long-term vitreous tamponade: in vivo investigation using perfluorocarbon liquids and semi-fluorinated alkanes. Graefes Arch Clin Exp Ophthalmol. 2007;245:665-675.

20. Flores-Aguilar M, Munguia D, Loeb E, et al. Intraocular tolerance of perfluorooctylbromide (perflubron). Retina. 1995;15:3-13.

21. Zeana D, Becker J, Kuckelkorn R, Kirchhof B. Perfluorohexyloctane as a long-term vitreous tamponade in the experimental animal. Experimental perfluorohexyloctane substitution. Int Ophthalmol. 1999; 23:17-24.

22. Abrams GW, Azen SP, McCuen BW 2nd, et al. Vitrectomy with silicone oil or long-acting gas in eyes with severe proliferative vitreoretinopathy: results of additional and long-term follow-up. Silicone Study report 11. Arch Ophthalmol. 1997;115:335-344.

23. Duan A, She H, QiY. Complications after heavy silicone oil tamponade in complicated retinal detachment. Retina. 2011;31:547-552.
Clinical Ophthalmology

\section{Publish your work in this journal}

Clinical Ophthalmology is an international, peer-reviewed journal covering all subspecialties within ophthalmology. Key topics include: Optometry; Visual science; Pharmacology and drug therapy in eye diseases; Basic Sciences; Primary and Secondary eye care; Patient Safety and Quality of Care Improvements. This journal is indexed on Submit your manuscript here: http://www.dovepress.com/clinical-ophthalmology-journal

\section{Dovepress}

PubMed Central and CAS, and is the official journal of The Society of Clinical Ophthalmology (SCO). The manuscript management system is completely online and includes a very quick and fair peer-review system, which is all easy to use. Visit http://www.dovepress.com/ testimonials.php to read real quotes from published authors. 